\title{
Changing infant feeding practices and declining incidence of coeliac disease in West Somerset
}

\author{
D N Challacombe, I K Mecrow, K Elliott, F J Clarke, E E Wheeler
}

\begin{abstract}
An association was investigated between changing infant feeding practices and a declining incidence of childhood coeliac disease and transient gluten intolerance (TGI) in West Somerset, England during 1971-92. Dietary histories of 18 patients with coeliac disease were compared with 23 controls during 1971-80 and eight patients with coeliac disease and 39 controls during 1981-92. Our findings showed that the declining incidence of coeliac disease and TGI were associated with changing infant feeding practices, characterised by the later introduction of dietary gluten, an increased use of baby rice and gluten free foods for weaning, and an increased incidence of initial breast feeding.

(Arch Dis Child 1997;77:206-209)
\end{abstract}

Keywords: coeliac disease; declining incidence; infant feeding

The incidence of coeliac disease in childhood has declined in England, ${ }^{1-4}$ Scotland, ${ }^{5}$ and Ireland $^{6}$ over the past two decades. However, in Italy, the incidence has been unchanged, ${ }^{7}$ and probably in Finland, ${ }^{8}$ where patients increasingly present with mild or atypical symptoms and signs of coeliac disease, at school age or during adolescence. In Sweden, the incidence of coeliac disease has increased since $1982 .{ }^{9}{ }^{10}$ The reasons for these conflicting trends are unclear, with genetic and environmental factors being implicated, including the age of introducing dietary gluten in infancy. ${ }^{11}$ In this study we have investigated the influence of changing infant feeding practices on the incidence of childhood coeliac disease and transient gluten intolerance (TGI) in West Somerset, during 1971-92.

Patients and methods

West Somerset had a mean annual population of 263000 (51 $600<14$ years) during 1971-92 and a mean number of live births of 2700 per annum.

During this period, 39 children with a history of coeliac disease (22 boys, 17 girls; median age $=16$ months, range $=3$ months -13 years 8 months) were admitted to the children's unit, Taunton and Somerset Hospital for further investigation. Peroral small intestinal biopsy specimens showed villous flattening by light microscopy, and they responded clinically to treatment with a gluten free diet. An initial diagnosis of coeliac disease was made and later confirmed on 16 patients (six boys, 10 girls), according to criteria of the European Society for Paediatric Gastroenterology and Nutrition (ESPGAN). ${ }^{12} \mathrm{~A}$ further 10 patients (five boys, five girls) were diagnosed with coeliac disease according to revised ESPGAN criteria. ${ }^{13}$ The age of presentation of coeliac disease in all patients was the time of their initial biopsy and the cumulative incidence of coeliac disease was the number of patients per 1000 live births, calculated for each birth cohort.

Dietary histories during infancy were obtained on patients and controls by a paediatric dietitian. The numbers of infants initially breast or bottle fed, the age of introduction of dietary gluten, and the types of solids used for weaning were determined. Controls were children admitted to hospital in whom coeliac disease was excluded and 23 were studied between 1971-80 (16 boys, seven girls; median age $=15$ months $)$ and 39 between 1981-92 (19 boys, 20 girls; median age $=22$ months).

Histological sections of biopsy specimens from patients were examined by light microscopy and graded by experienced observers (DNC, IKM) as follows:

Grade 1-villi of normal height, normal epithelial cell appearances, and a normally cellular lamina propria.

Grade 2-villous flattening varying from mild to moderate, loss of epithelial cell height, and increased cellularity of the lamina propria.

Grade 3-a flat mucosal surface with a cuboidal epithelium and heavy cellular infiltration of the lamina propria.

\section{Results}

COELIAC DISEASE

Of 39 patients first diagnosed with coeliac disease (22 boys, 17 girls), 29 had grade 3 histopathological changes by light microscopy and 10 had grade 2 changes. After two years on a gluten free diet, 29 (17 boys, 12 girls) had biopsy specimens taken from them again and had a normal mucosa. They were challenged with gluten and 16 (six boys, 10 girls) had a positive challenge with grade 3 changes and 13 (11 boys, two girls) a negative challenge with grade 1 changes. Ten patients (five boys, five girls) were diagnosed with coeliac disease after a single biopsy showing grade 3 changes, without a gluten challenge. ${ }^{13}$

Altogether 26 children with coeliac disease were diagnosed between 1971-92 (11 boys, 15 girls; median age $=15$ months; range $=4$ months -165 months (13 years 9 months)); 18 during 1971-80 (median age $=13$ months; range $=4$ months -156 months (13 years) and eight during 1981-92 (median age $=21$ months; range $=9$ months -165 months. ${ }^{13}$ The annual incidence of coeliac disease peaked in 


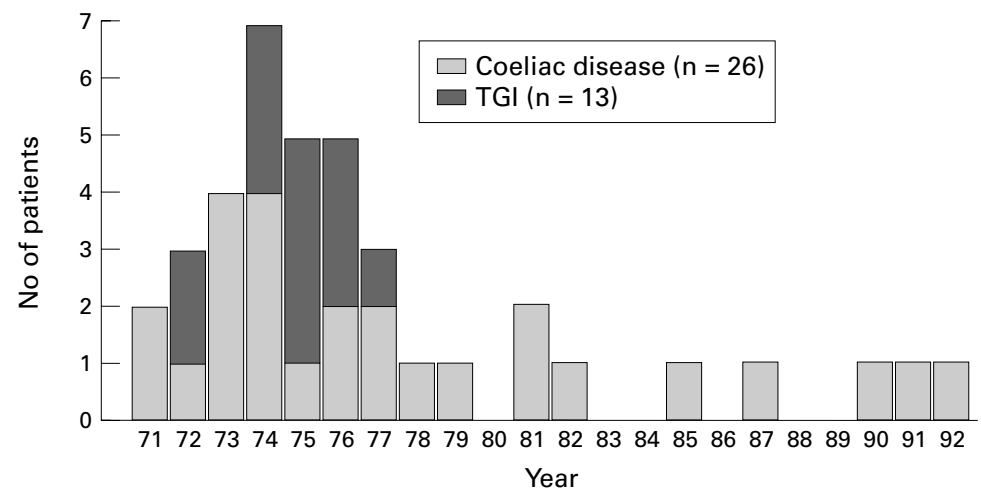

Figure 1 The incidence of coeliac disease and TGI in West Somerset (1971-92).

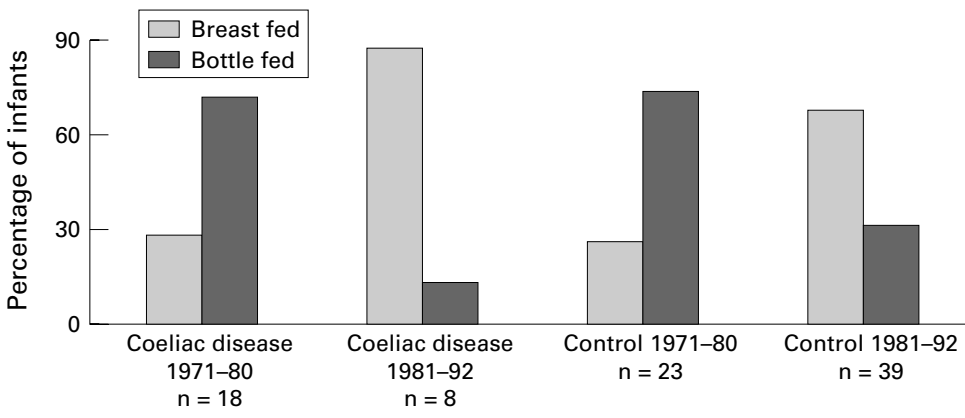

Figure 2 Proportions of children with coeliac disease and controls initially breast or bottle fed $(\%)$.

1974 and then declined, and no patients were diagnosed annually for six years between 1980-92 (fig 1). The cumulative incidence of coeliac disease was 0.68 per 1000 live births in children born during 1971-80 and 0.09 per 1000 live births during 1981-92.

TRANSIENT GLUTEN INTOLERANCE

Of the 39 patients first diagnosed with coeliac disease, 13 ( 11 boys, two girls; median age $=9$ months, range $=3-44$ months $(3$ years 8 months)) showed grade 3 histopathological changes in three and grade 2 changes in 10, but had a negative gluten challenge. They were diagnosed with TGI, but not all criteria for making this diagnosis were fulfilled, ${ }^{14}{ }^{15}$ and food allergies were not excluded. Five patients were initially breast fed and eight bottle fed,

Table 1 The age of introducing gluten and the incidence and age at diagnosis of coeliac disease (median and range)

\begin{tabular}{llll}
\hline & $N o$ & $\begin{array}{l}\text { Age of introducing gluten } \\
\text { (months) }\end{array}$ & $\begin{array}{l}\text { Age at diagnosis } \\
\text { (months) }\end{array}$ \\
\hline $\begin{array}{l}\text { Children with coeliac disease } \\
1971-80\end{array}$ & 18 & $3(1.3-10)$ & $13(4-156)$ \\
$\begin{array}{c}1981-92 \\
\text { Controls }\end{array}$ & 8 & $5.5(3-8)(\mathrm{p}=0.01)$ & $21(9-165)(\mathrm{p}=0.09)$ \\
$1971-80$ & 23 & $3(0.5-5)$ & \\
$1981-92$ & 39 & $5.5(1.5-13)(\mathrm{p}<0.0001)$ & \\
\hline
\end{tabular}

Table 2 Initial breast and bottle feeding, the age of gluten introduction, and the age at diagnosis of coeliac disease (median and range)

\begin{tabular}{|c|c|c|c|}
\hline & No & $\begin{array}{l}\text { Age of introducing gluten } \\
\text { (months) }\end{array}$ & Age at diagnosis (months) \\
\hline \multicolumn{4}{|c|}{ Children with coeliac disease } \\
\hline Breast fed & 12 & $5(3-8)$ & $21(9-165)$ \\
\hline Bottle fed & 14 & $3(1-9)(\mathrm{p}=0.03)$ & $11.5(4-144)(\mathrm{p}=0.03)$ \\
\hline \multicolumn{4}{|l|}{ Controls } \\
\hline Breast fed & 34 & $4.5(1.5-13)$ & \\
\hline Bottle fed & 28 & $3(0.5-6.5)(p=0.01)$ & \\
\hline
\end{tabular}

and gluten was introduced at a median age of 3 months (range $=1-9$ months). The incidence of TGI declined during the early 1970 s and no patients were diagnosed after 1977.

CHANGING INFANT FEEDING PRACTICES IN INFANTS WITH COELIAC DISEASE AND CONTROLS Data on the age at which particular events occurred are medians with $95 \%$ confidence intervals (CI). Statistical analysis of differences between groups was obtained using the MannWhitney U test.

Table 1 shows that patients with coeliac disease during 1971-80 were diagnosed at 13 months and during 1981-92 at 21 months $(p=0.09)$. Gluten was introduced to coeliacs at 3 months during $1971-80$ (95\% CI 2.3 to 5.0 ) and at 5.5 months during 1981-92 (5.0 to 7.3) $(\mathrm{p}=0.01)$. Gluten was introduced to controls at 3 months during $1971-80$ (2.0 to 3.0 ) and at 5.5 months during 1981-92 (4.5 to 6.0) $(\mathrm{p}<0.0001)$. The results showed that later introduction of gluten during 1971-92 was associated with a declining incidence of coeliac disease and an increased age of presentation.

Figure 2 shows that during 1971-80, 72\% of children with coeliac disease and $74 \%$ of controls were initially bottle fed, and $28 \%$ of children with coeliac disease and $26 \%$ of controls were initially breast fed. During $1981-92,87 \%$ of children with coeliac disease and $69 \%$ of controls were initially breast fed and $13 \%$ of children with coeliac disease and $31 \%$ of controls were initially bottle fed.

Table 2 shows that during 1971-92, gluten was introduced later to breast fed than bottle fed children with coeliac disease $(\mathrm{p}=0.03)$ and to breast fed than bottle fed controls $(p=0.01)$. Breast fed children with coeliac disease were diagnosed later than bottle fed children with coeliac disease $(p=0.03)$.

Figure 3 shows that children with coeliac disease during 1971-80 were initially weaned onto foods containing gluten, such as wheat cereals $(50 \%)$, rusks $(45 \%)$, and commercial baby foods (5\%), and during 1981-92 onto wheat cereals $(63 \%)$, rusks $(12 \%)$, and commercial baby foods (25\%). Controls during 1971-80 were also weaned onto wheat cereals (65\%) and rusks (35\%), but during 1981-92 onto wheat cereals $(5 \%)$, rusks $(20 \%)$, gluten free commercial baby foods $(17.5 \%)$, and baby rice (milled rice with added thiamine) $(57.5 \%)$.

\section{Discussion}

Early estimates of the incidence of childhood coeliac disease in the UK were based on diagnoses using clinical criteria. ${ }^{16-19}$ Since 1970, however, the diagnosis has been based on small bowel biopsy according to criteria agreed by ESPGAN, ${ }^{12}{ }^{13}$ and the incidence has varied from 1:500 to $1: 3000$, with a mode of around $1: 1000$ live births. ${ }^{20}$

In this study the incidence of coeliac disease in West Somerset declined from 1:1228 during 1971-80 to 1:4168 during 1981-92. A declining incidence was also reported from the Edinburgh and Lothian region of Scotland after 1976, after a more than twofold increased incidence 


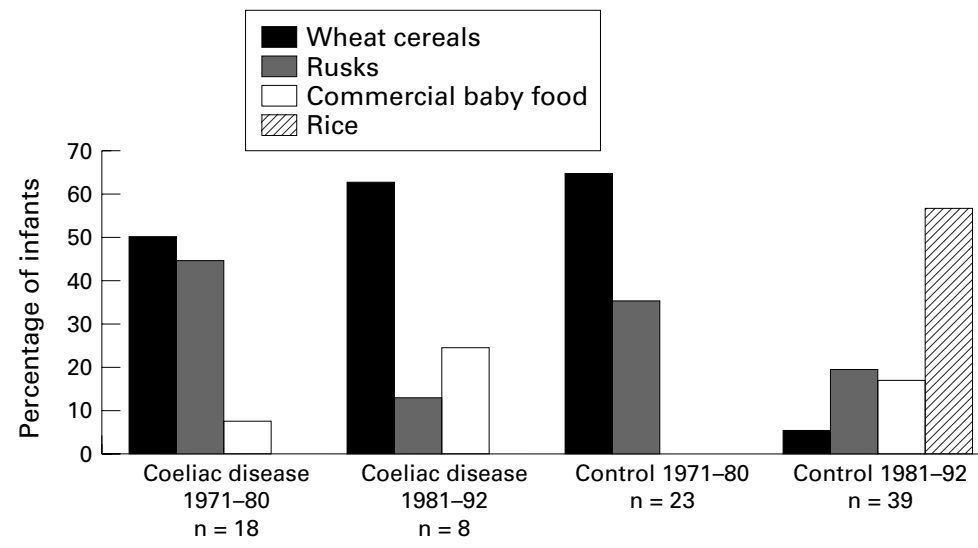

Figure 3 Weaning solids first given to children with coeliac disease and controls (\%).

from 1960-75. ${ }^{5}$ These findings could have represented a true reduction in the incidence of coeliac disease or a declining incidence from a high level in the late 1960s and early 1970s, possibly due to changing infant feeding practices. Studies of records from the Royal Hospital for Sick Children, Glasgow showed that increased numbers of children with coeliac disease were admitted during 1958-65 and 1966-73 than during 1950-57 and that patients were diagnosed earlier in the two later periods. ${ }^{21}$ Cereals containing gluten were also introduced earlier in Glasgow during 1958-63, and $91 \%$ of infants were given gluten by three months of age in $1965 .{ }^{21}$ The early introduction of gluten in infancy could also have contributed to the high incidence of coeliac disease in the West of Ireland during $1960-70,{ }^{22}$ and to a reduction in the mean age of presentation of coeliac disease in England during $1964-72 .^{23}$

In 1974 , a report from the Department of Health and Social Security (DHSS) Working Party of the Panel on Child Nutrition, encouraged breast feeding and discouraged the early introduction of cereals or other solid foods into the diet of infants before 4 months of age and the addition of cereals to bottle feeds. ${ }^{24}$ These recommendations were effected in West Somerset in the early 1970 s and the median age of introducing gluten to patients with coeliac disease increased from 3 months during 1971-80 to 5.5 months during 1981-92. The median age of presentation of coeliac disease also increased during these periods, from 13 to 21 months. These dietary changes could have caused the declining incidence of coeliac disease in susceptible infants as well as the declining incidence of TGI. ${ }^{15}$ Another contributory factor could have been the increased availability of commercial gluten free weaning foods, which rose from 72 in 1970 to 205 in 1989/90 (Coeliac Society (UK) handbook). Other infant feeding surveys also confirmed that infants were being weaned onto solids six weeks later in 1980 than in $1975,,^{25-27}$ but weaning practices were relatively unchanged between $1980-90 .^{28}$

An increased incidence of initial breast feeding in children with coeliac disease and controls in West Somerset during 1971-92 and in other infant feeding surveys, could have contributed to the declining incidence of coeliac disease and TGI. ${ }^{27}{ }^{28}$ Breast fed children with coeliac disease and controls in West Somerset were given dietary gluten later than bottle fed children with coeliac disease and controls, and breast fed children with coeliac disease presented later than bottle fed children with coeliac disease. In another study the number of infants initially bottle fed with cows' milk formulas during 1971-80 decreased during 1981-92. ${ }^{6}$ An increase in initial breast feeding may have protected the small intestinal mucosa against 'priming' by gluten, and possibly by other dietary antigens as well. ${ }^{25}$

In Sweden, a doubling of the gluten content of proprietary baby foods was associated with an increased incidence of coeliac disease, from 1.7 children per 1000 live births during 1978-82 to 3.5 per 1000 thereafter..$^{9}{ }^{10}$ This occurred in spite of an increased prevalence and duration of breast feeding, and delay in the introduction of dietary gluten from 4 to 6 months. ${ }^{10}$ The clinical response to gluten in patients with coeliac disease is known to be dose dependent, ${ }^{29}{ }^{30}$ and an overall reduction in the amount of gluten given during infancy could have been another factor contributing to the declining incidence of coeliac disease in West Somerset.

In this study, the findings suggested that changing infant feeding practices contributed to the declining incidence of coeliac disease during 1971-92 and to the disappearance of TGI. ${ }^{15}$ The dietary findings supported the recommendations made by the DHSS Working Party of the Panel on Child Nutrition in $1974 .^{24}$ Also that baby rice and gluten free foods should initially be given to wean infants onto solids and that dietary gluten should be avoided until at least 5 months of age.

We are grateful to the staff of the children's unit, Taunton and Somerset Hospital, for their assistance with this study and to Mrs Trish Hilton, Dr Paul Ewings, and Mrs Katharine Kent. Also to Professor BA Wharton and Dr JA Black for their useful comments and to the trustees of the Somerset Children's comments and to the trustees of the
Research Unit for their valuable support.

1 Littlewood JM, Crollick AJ, Richards IDG. Childhood coeliac disease is disappearing. Lancet 1980;ii: 1359

2 Challacombe DN, Baylis JM. Childhood coeliac disease is disappearing. Lancet 1980;ii:1360.

3 Dossetor JFB, Gibson AAM, McNeish AS. Childhood coeliac disease is disappearing. Lancet 1981;i:322-3.

4 Langman MJS, McConnell TH, Spiegelhalter DJ, McConnell RB. Changing patterns of coeliac disease frequency; an analysis of coeliac society membership records. Gut 1985;26:175-8.

5 Logan RFA, Rifkind EA, Busittil A, Gilmour HM, Ferguson A. Prevalence and 'incidence' of celiac disease in Edinburgh and the Lothian region of Scotland. GastroenterEdinburgh and the Lothic

6 Stogy 1986;90:334-42. Stevens FM, Egan-Mitchell B, Cryan E, McCarthy CF,
McNicholl B. Decreasing incidence of coeliac disease. Arch Dis Child 1987;62:465-8.

7 Greco L, Tozzi AE, Mayer M, Grimaldi M, Silano G, Auricchio S. Unchanging clinical picture of coeliac disease presentation in Campania, Italy. Eur $\mathcal{F}$ Pediatr 1989;148: 610-3.

8 Maki M, Kallonen K, Lahdeaho M-L, Visakorpi JK. Changing pattern of childhood coeliac disease in Finland. Acta Paediatrica Scandinavica 1988;77:408-12.

9 Ascher H, Krantz I, Kristiansson B. Increasing incidence of coeliac disease in Sweden. Arch Dis Child 1991;66:608-11.

10 Cavell B, Stenhammar L Ascher $\mathrm{H}$, et al. Increasing Cavell B, Stenhammar $\mathrm{L}$, Ascher $\mathrm{H}$, et al. Increasing incidence of coeliac disease in Sweden. Results of a
national study. Acta Paediatr 1992;81:589-92. national study. Acta Paediatr 1992;81:589-92.

Challacombe DN. The incidence of coeliac disease and early weaning. Arch Dis Child 1983;58:326.

12 Meeuwisse GW. Diagnostic criteria in coeliac disease. Acta Paediatrica Scandinavica 1970;59:461-3. 
13 Walker-Smith JA, Guandalini S, Schmitz J, Schmerling DH, Visakorpi J. Revised criteria for diagnosis of coeliac disease. Report of working group of European Society of Paediatric Gastroenterology and Nutrition. Arch Dis Child 1990;65: 909-11.

14 McNeish AS, Rolles CJ, Arthur LJH. Criteria for the diag nosis of temporary gluten intolerance. Arch Dis Child 1976 51:275-8.

15 Walker-Smith JA. Transient gluten intolerance. Does it exist? Neth $\mathcal{F}$ Med 1987;93:1356-62.

16 Davidson LSP, Fountain JR. Incidence of the sprue syndrome with some observations on the natural history. BMF 1950;1:1157-61.

17 Black JA. Possible factors in the incidence of coeliac disease. Acta Paediatr 1964;53:109-16.

18 Carter C, Sheldon W, Walker C. The inheritance of coeliac disease. Ann Hum Genet 1959;23:266.

19 McCrae WM. Inheritance of coeliac disease. 7 Med Genet 1969;6:129-31.

20 Auricchio S, Greco L, Troncone R. Gluten-sensitive enteropathy in childhood. Pediatr Clin North Am 1988;35:157opath
87.

21 Arneil GC. Dietary study of 4365 Scottish infants: 1965 . Scottish health service studies No 6. Edinburgh: HMSO, 1967 89.
22 Mylotte M, Egan-Mitchell B, McCarthy CF, McNicholl B. Incidence of coeliac disease in the West of Ireland. $B M \mathcal{F}$ 1973;i:703-5.

23 McNeish AS, Anderson CM. Coeliac disease: the disorder in childhood. In: Cooke WT, Asquith P, eds. Clinics in gastroenterology. Vol. 3. London: Saunders, 1974:127-44.

24 Panel on Child Nutrition Working Party on Infant Feeding. Present-day practice in infant feeding. Report on health and social subjects No 9. London: HMSO, 1974:24-6.

25 Wharton BA, Edwards C. Early diet and later disorders of the gut. Bulletin of the British Nutrition Foundation the gut. Bulletin of

26 Wharton BA. A quinquennium in infant feeding. Arch Dis Child 1982;57:895-6.

27 Martin J, Monk J. Infant feeding: 1980. London: Office of Population Censuses and Surveys, 1982:21-6.

28 White A, Freeth S, O'Brien M. Infant feeding: 1990. London: Office of Population Censuses and Surveys, 1990:8-32.

29 Challacombe DN, Dawkins PD, Baylis JM, Robertson K. Small-intestinal histology in coeliac disease. Lancet 1975;i: 1345-6.

30 Kumar PJ, O'Donoghue DP, Stenson K, Dawson AM. Reintroduction of gluten in adults and children with treated coeliac disease. Gut 1979;20:743-9. 